American Journal of Applied Sciences 6 (6): 1086-1092, 2009

ISSN 1546-9239

(C) 2009 Science Publications

\title{
Petrography and Sulphur Isotope Studies of Pyrites in the Muteh Gold Deposit
}

\author{
${ }^{1}$ M.J. Abdollahi, ${ }^{2}$ M.H. Karimpour and ${ }^{1}$ A. Kheradmand \\ ${ }^{1}$ Department of Geology, Shahid Bahonar University, Kerman, Iran \\ ${ }^{2}$ Department of Geology, Ferdousi University, Mashhad, Iran
}

\begin{abstract}
Problem statement: The Muteh mining district is located in $70 \mathrm{~km}$ northeast of Golpaygan city within the Sanandaj-Sirjan metamorphic belt. There are 2 gold mines, 7 gold occurrences and numerous mineral indices in the Muteh gold district. There are few researches on Muteh gold district, but a detailed model is not clear yet. The aim of this study is to determine mineralogy of gold-bearing rocks and the role of these rocks in concentration of gold and to improve our knowledge about Muteh model. Approach: Detailed fieldwork carried out at different scales at the Muteh district. About 50 outcrops samples examined petrographically. Fifteen samples containing veinlets of sulfides and quartz selected for $\mathrm{H}, \mathrm{O}$ and $\mathrm{S}$ stable isotope analysis. Petrography characterized by optical microscopy, Scanning Electron Microscopy (SEM) and X-Ray powder Diffraction (XRD) analysis. Results: Geological studies indicated that the study area show a major poly-phase metamorphism. Since the latest metamorphism was weaker than the earlier ones, the older rocks were affected by more intense metamorphism. The metamorphic rocks mainly consist of schists, quartzite, marble, amphibolite and gneisses. These rocks show two foliations $\left(S_{1}\right.$ and $\left.S_{2}\right)$. The $S_{2}$ foliation is the major phase in the metamorphic rocks. Pyrite is the most abundant and the important gold-bearing mineral at the study area. Based on evidences of deformation $\left(S_{2}\right)$ and crystallization, three main types of pyrites can be distinguished in the Muteh deposit: (1) pre-tectonic or gold bearing pyrite (2) syn-tectonic or disseminated pyrites along the foliation of the host rocks. (3) pyrite aggregates in the host rocks or in the metamorphic segregation quartz veins crosscutting the foliation of the host rocks. The sulfur isotope studies were carried out on pyrites within quartz veinlets, biotite schist and meta-volcanic rocks at the Muteh deposit. Five available data are highly variable even from the same types of hosted rocks and their $\delta^{34} \mathrm{~S}$ are $+2.2,6.6,9.1,13.9$ and $16.9 \%$. Conclusion: There are three generations of pyrite in Muteh gold district. According to isotope data, it seems that source of sulfurs were not homogenous. The values showed more than one geological event for generation of pyrites in the study area. Compositions of sulfur isotopes indicated several different sources or processes for the sulfide fluids. The sulfur of these pyrites might have derived either directly from regional metamorphism that produced the metamorphic fluid or through dissolution and leaching of pre-existing sulfide-bearing minerals.
\end{abstract}

Key words: Pyrites, Muteh gold district, foliation, metamorphic rocks, sulfur isotope

\section{INTRODUCTION}

There are two gold mines, seven gold occurrences and numerous mineral indices in the Muteh gold district, which covers $160 \mathrm{~km}^{2}$ in northeast of the metamorphic basement within Sanandaj-Sirjan metamorphic Zone (SSZ). Gold mineralization occurs in pre-Permian metamorphic ${ }^{[13]}$ complex, which mainly consist of gneisses, green schists and meta-volcanic rocks. Gold mineralization is closely associated with intense hydrothermal alterations that occur along the normal faults and along the ductile shear zones. Gold is the ancient ore mineral in the study area. Chah-
Khatoon, Senjedeh and Darreh-ashki are three occurrences, which currently mined for gold in the Muteh area (Fig. 1). These mines are the most productive gold deposit in Iran since 1950. The gold mineralization is associated with metamorphic rocks of predominantly meta-volcanic and schist composition. The Muteh metamorphic complex consists of a highgrade metamorphic core (mainly gneiss and amphibolite) and low-grade metamorphic rocks (mainly schists and marbles) in the upper parts. Despites the fact that these deposits were long under exploitation ${ }^{[1,3,17]}$ there are no sufficient data to make a comprehensive genetic model. 

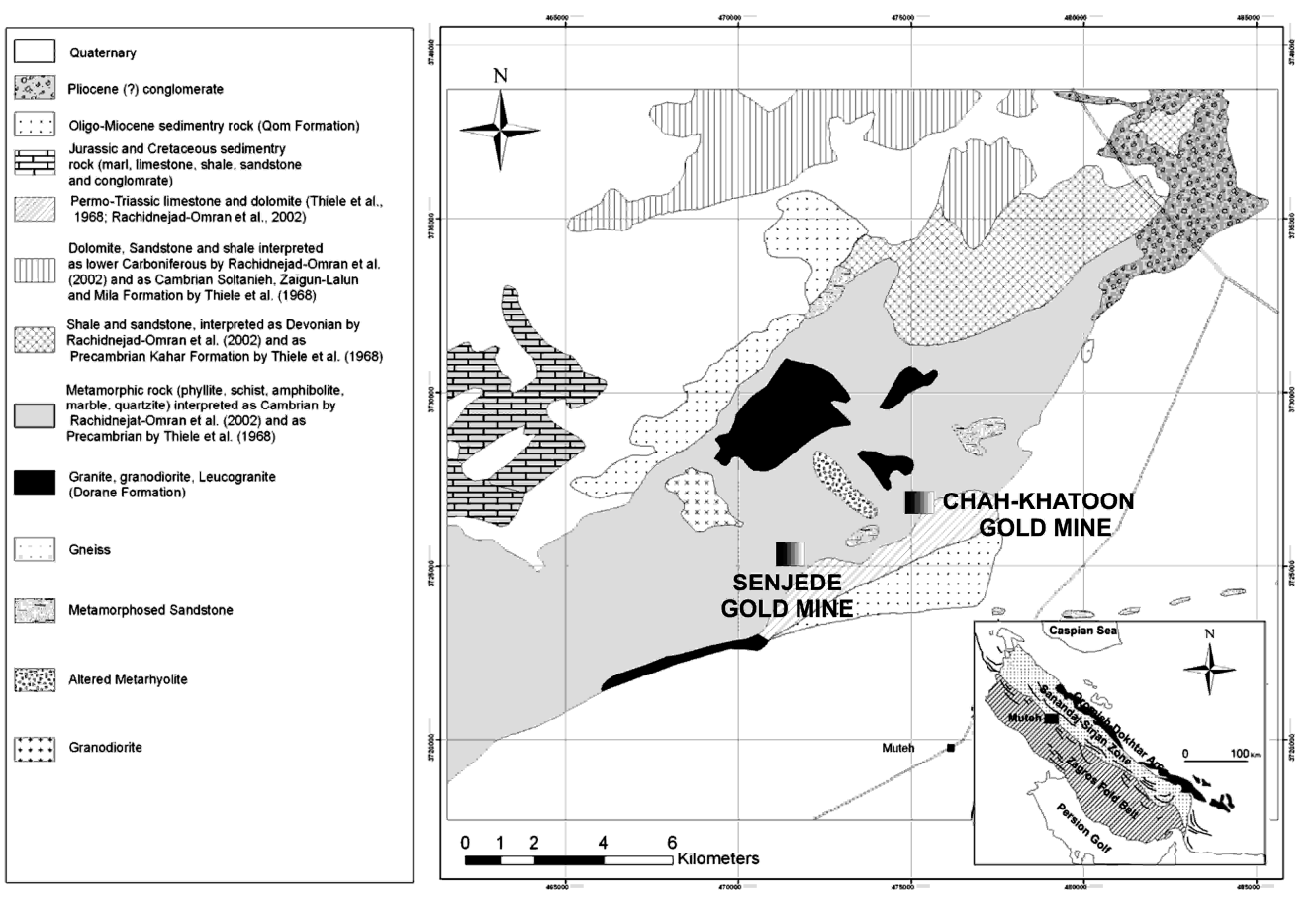

Fig. 1: Simplified geology and tectonic setting of Iran and study area showing relative location of Chah-Khatoon and Senjedeh gold mines

Geology: The Muteh gold deposit is located in the Sanandaj-Sirjan Zone and occurred in pre-Permian rocks. This area consists of a variable sequence of quartz, sericite and albite+chlorite+biotite schists with a well-developed foliation surrounded by Mesozoic to Quaternary sediments. These pre-Permian basement rocks form a narrow, mountainous, northeast trending belt, which probably bounded by faults. The area had been under poly-metamorphism such as dynamo thermal, contact, dynamic and hydrothermal metamorphism. Golpaygan-Muteh inlier contains rock assemblages, which deformed during three deformation stages and metamorphosed by two regional metamorphism events. This inlier with NE-SW trend separated from younger sediments by sets of restricting faults. Their kinematics is reverse with left-lateral components of displacements. Three younger sets of faults displaced the former faults. NW-SE trending faults have the most obvious displacement. The structural trends of first and second stages of deformations are concordant with the major NW-SE structural trend of the Sanandaj-Sirjan zone but the third stage have genetic relation to the boundary faults of the inlier trending discordant to the main trend of the Sanandaj-Sirjan zone. Initiation of the NE-SW trending inlier were the result of extension tectonic with active restricting normal faults building horst and graben structures and followed by later deformations under transpression tectonic regime of the Sanandaj-Sirjan zone $^{[11]}$. Since the last metamorphism was weaker than the earlier ones, the older rocks were under more intense metamorphism such as sericitization and chloritization $^{[19]}$.

Based on lithology, metamorphic facies and even the style of deformations, three separable complexes as gneiss complex, green-schist complex and slate complex, from bottom to top, have been detected ${ }^{[16]}$.

The pre-Permian schists commonly show relic fragmental textures and interpreted to be metamorphosed acid volcanics, tuffs and sediments (metarhyolite). The original schistose texture largely destroyed by the alteration, which presumably postdates peak metamorphism. The schists intruded by granite intrusions and in some localities overlain to the northeast by unmetamorphosed rock. Ar/Ar dating on various samples of these granitoid bodies indicate that they have emplaced in Middle to Late Cretaceous, Late Paleocene and Paleocene-Eocene ${ }^{[17]}$, but recent $\mathrm{U}-\mathrm{Pb}$ analysis on zircon minerals revealed $540 \pm 10 \mathrm{~m}$ y for the granitoid bodies ${ }^{[5]}$. The effects of Late Cimmerian and Laramian orogenies and their related acidic plutonism, have partly obliterated all the previous events in this region, but the Early Cimmerian orogenic event has stressed as the most important metamorphic 
deformation event in the southeastern part of SanandajSirjan zone. The gold deposits are vein or lode style and mostly formed in the schists. Mineralization is correlates with tectonic, metamorphic and hydrothermal activities. Hassanzadeh et al.$^{[5]}$ have been determined age of granites in the study area using zircon single crystal U-Pb geochronology as $540 \pm 10 \mathrm{Ma}$. Therefore based on contact metamorphism features in the host rock due to emplacement of these granites can conclude that the age of schists host rock is older than the granites.

Gold mineralization occurs in metamorphic sequences, which mainly consist of green schists, metarhyolites, gneisses and volcano-sedimentary rocks and less often, at the margins of granite intrusions. Shear zones are the host of gold mineralization and intense alterations occur along the normal faults trending $\mathrm{N}_{2} 5 \mathrm{~W}^{[1]}$. The mineralized zones form moderate to steeply dipping and tabular bodies. Individual veins are generally small and irregular. Mafic silicate minerals in the host rocks (chlorite, biotite and amphibole) replaced by fine-grained quartz and sericite in some localities. Gold mineralization is characterized by bleaching, silicification and sericitization of the host rocks and some times by local brecciation and quartz-pyrite veining.

Based on the field observations and petrographical studies, pyrite is the most important gold bearing mineral and ubiquitous in the schists and metarhyolite. Evidences shows that, pyritization in this region are rather extensive and mostly is concentrated in veinlets and in some places disseminated in the rocks. Hydrothermal fluids originated from intrusive bodies and metamorphisms have gone through the cracks and fractures zones. It seems that auriferous pyrite mostly restricted to quartz veins and crosscutting veinlets. The gold is very fine-grained (1-5 $\mu)$ and visible gold grains have not been reported. Geometry and localization of lode gold deposits strongly influenced at all scales by structure $^{[6,18]}$. This relationship is particularly evident in fractured districts, such as those associated with Precambrian greenstone belts in the Canadian Shield, where the majority of the gold deposits are spatially associated with crustal-scale, brittle-ductile shear zones $^{[10,18]}$. Geology of two main gold deposits in the Muteh district is summarized below:

The gold mineralization at Senjedeh Deposit occurred in the pre-Permian metamorphic basement of Sanandaj-Sirjan tectonic zone consists of gneisses, amphibolites, schist, quartzite and phyllites ${ }^{[12]}$. The presence of relic fragmental texture in schist indicates that protolith was an acid volcanics and tuffs ${ }^{[4]}$. The metamorphic basement has been intruded by abundant granitic intrusions. The Senjedeh deposit contains $0.84 \mathrm{Mt}$ oxide ore and $0.91 \mathrm{Mt}$ sulphide ore. The thickness of oxide zone varies from $8-40 \mathrm{~m}$ in ChahKhatoon and Senjedeh deposits. This deposit contains two separate lodes, which both occurred around discrete fault plans. In the Senjedeh mine, basaltic dykes metamorphosed to amphibolite facies. Gold irregularly distributed throughout the ore zones, as is typical in this style of deposit. The gold commonly occurs as inclusions in the pyrite in the sulphide zone. Chalcopyrite, pyrrhotite, sphalerite and galena also have been reported from the ore zones. Copper mineralization is conspicuous at Senjedeh by the presence of secondary minerals such as chalcanthite; however, the copper content of the ore at ChahKhatoon has not been determined

Chah-Khatoon is a single, thick gold ore zone (lode). The lode dips to the north east at about $40^{\circ}$ and appears to be up to $20 \mathrm{~m}$ thick. Within this zone are smaller zones of very high-grade mineralization which are oriented parallel to the plane of the lode. High gold assays are associated with silicification, quartz-pyrite veining and sharply defined, narrow, ochreous fault planes. Low-grade gold mineralization $\left(1-3 \mathrm{~g} \mathrm{t}^{-1}\right)$ is more difficult to identify by naked eyes, or field observation but SEM show the gold is associated with thin quartz-pyrite veinlets. The ore weakly oxidized near the surface, forming a thin oxidized cap on the deposit. Oxidation has resulted in the formation of limonite pseudomorphs after pyrite and weak staining of the ore by remobilized iron. The silicate minerals in the ore generally only weakly affected by oxidation and the oxide ore remains hard and compact.

\section{MATERIALS AND METHODS}

Detailed fieldwork carried out at different scales at the Muteh district, at two deposits (Chah-Khatoon and Senjedeh mines) and in the metamorphic rocks. Fieldwork and sampling carried out during the summer of 2004-2005. About 50 outcrops samples from different type of quartz veins containing pyrites and associated with metamorphic rocks examined petrographically. Fifteen samples containing veinlets of sulfides and quartz selected for $\mathrm{H}, \mathrm{O}$ and $\mathrm{S}$ stable isotope analysis. Petrography characterized by optical microscopy, Scanning Electron Microscopy (SEM) and X-Ray powder Diffraction (XRD) analysis in Shahid Chamran University of Ahvaz, Iran. Sulfur, isotope value of pyrites, were determined on hand-picked mineral separates at the Isotope Laboratory, Dept. of Earth Sciences, Queens University, Canada, using a continuous flow elemental analyzer (Carlo Erba NA 1500) attached 
to a VG Prism II mass spectrometer. These minerals were separated from crushed and sieved samples using conventional heavy liquids (sodium polytungstate; specific gravity $=2.9$ ) followed by handpicking under a binocular microscope.

Deformation and metamorphism relations with especial aspect on the formation of pyrites: Muteh gold deposits contains rock assemblages which were deformed during three deformation stages and metamorphosed by two regional metamorphism events. Three generation of pyrite recognized in sulphide ore.

Development of foliation stages in metamorphic rocks of Muteh: The $S_{1}$ foliation is defined by slate cleavage and is contemporaneous with $D_{1}$ deformational phase. The $S_{2}$ foliation is defined by well-developed crenulation cleavage.

This foliation is dominant in the study area and observed in the most rocks. The metamorphic rocks contemporaneous with this deformation phase (D2) are green-schist facies. Based on $^{[15]}$, this foliation is continuous type and occurs in micaceous schists.

The growth of pyrites porphyroblasts in relation with plate-tectonic:

Pre-tectonic pyrites: Many of pre-tectonic pyrites show pressure shadow textures. Since these pyrites formed before any deformational stages, usually show some degrees of strain in their grains. In the study area, some pyrites sheared because of relatively high strain and low temperature. This type of pyrites may account as pre-tectonic grains (Fig. 2a).

Syn-tectonic pyrites: Even though it is possible to see different phases of growth or recrystallization of minerals that happens contemporaneous with deformation in deformed rocks, but always it is not easy to distinguish the pre or syn-tectonic minerals. This resulted that minerals form during deformation time might have been under some strains and show a few characters of strain, which mentioned for pre-tectonic forming minerals. At study area, syn-tectonic minerals mostly defined by the long axis of elongate pyrites, which show preferred orientation with schistosity. However, schistosity wrapped around the synmetamorphism minerals and syn-tectonic minerals usually rolled over with schistosity (Fig. 2b).

Post-tectonic pyrites: Occurrence of pseudomorph minerals is one of the characteristic indicators for posttectonic minerals. This happens during retrograde metamorphism when $\mathrm{P}$ and $\mathrm{T}$ decrease. In the study

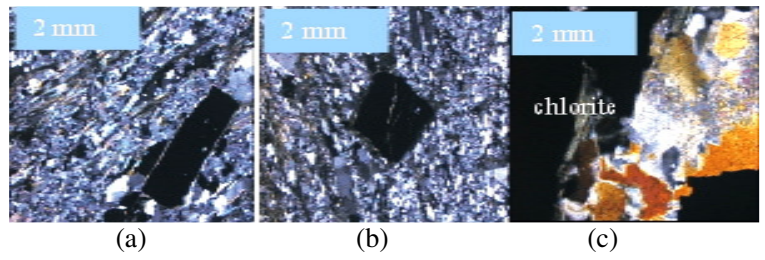

Fig. 2: Different types of pyrites at Muteh gold mines, (a): Pre-tectonic; (b): Syn-tectonic; (c): Posttectonic

area, post-tectonic pyrites are in adjacent with secondary chlorites. This may show that these minerals formed after alteration of biotite. This type of pyrites show random orientation with $\mathrm{S}_{2}$ schistosity (Fig. 2c).

SEM images show that during metamorphism, biotite and chlorites penetrated through the cracks and fractures of euhedral pyrites. Along the schistosity, micas surround metallic minerals such as pyrite and chalcopyrite. In some rocks, there are a close relation between euhedral pyrites and quartz veinlets. Some euhedral pyrites from Chah-Khatoon deposit show triple junction texture which caused by recrystallization of primary minerals from hydrothermal/metamorphic fluids. Adjacent to this type of pyrite grains, there is another type of pyrites showing intense fracturing.

In the Muteh gold district, pyrrhotite, chalcopyrite, bismuth and gold enclosed in some pyrites grains as inclusion $^{[7]}$. Some pyrites have iron-hydroxide replacement at their rims and are oriented along foliation. Kouhestani et al. ${ }^{[9]}$ have divided sulfide minerals such as pyrites, chalcopyrites and arsenopyrites into two generations. The first generation, are coarse euhedral ores scattering along the fractures, or formed next to quartz grains. Among these minerals, pyrites occur with a few millimeters dimensions, laminar features and oriented along schistosity. These pyrites introduced as synchronous with deformation and parallel with mylonitic foliation at study area. The second generation of pyrites and chalcopyrites are anhedral fine grains with no alteration element and are scattered within the altered rocks.

Ore mineralogy: Pyrite is the most abundant and the important gold-bearing mineral at Muteh gold district. Evidences show that, pyritization in this region is extensive and mostly is concentrated in quartz veinlets and in somewhere disseminated in the rocks. The mineralogical and metallurgical tests indicate that about $85 \%$ of gold is associated with pyrite and 15\% associated with quartz. Pyrite mainly occurs as disseminated and its aggregate only found in some veinlets. Even though most pyrite grains are 
idiomorphic but sub-idiomorphic and xenomorphic pyrites, are also abundant (Fig. 2a-c). In some localities, along the fracture and around the margin of pyrites replacement identifies by hematite, goethite and limonite. Tabular hematite grains pyrites' rims are an indicator of weathering and alteration after pyrite formation. Fine fractures (Fig. 2b) within pyrites show, they were not under strong compression pressure after formation. Brecciation that occurred in some pyrites can be as result of dynamic or fluids pressure (Fig. 3). Shearing which observed in some pyrites in the study area at microscopic scale is caused by extensional event. Some of these fractures that filled by chalcopyrites may show flowage of chalcopyrites during the metamorphism or might form postmetamorphism from reaction of pyrites with fluids containing copper solutions.

Sulfur isotope studies: The sulfur isotope data at the Muteh measured on pyrite in quartz veinlets and schists. Variation of $\delta^{34} \mathrm{~S}$ in the minerals and fluids may achieve by change of reduction state, temperature, $\mathrm{pH}$ and the primary amount of sulphur isotope in the source rocks.

Isotope data combine with petrography, SEM and content of sulfur (Table 1), indicate that three generation of pyrite are presence within the quartz veinlets and hosts rocks. The collected $\delta^{34} \mathrm{~S}$ values among the individual pyrite at Chah-Khatoon and Senjedeh gold deposits vary from 2.2-16.9\%o, however, the peak of $\delta^{34} \mathrm{~S}$ values is between 9 and $16 \%$ o (Table 1) with a mean value of $9.7 \%$. This suggests that the sulfides formed from fluids whose sulfur derived from metamorphic hosts' rock sources ${ }^{[14]}$. The sulfur might have derived either directly from regional metamorphism that produced the metamorphic fluid or through dissolution and leaching of pre-existing sulfidebearing minerals ${ }^{[14]}$. This feature may reflect that prePermian metamorphic rocks (e.g., Meta-volcanics and greenschists in the Muteh area) could have provided sulfur to the fluid system.

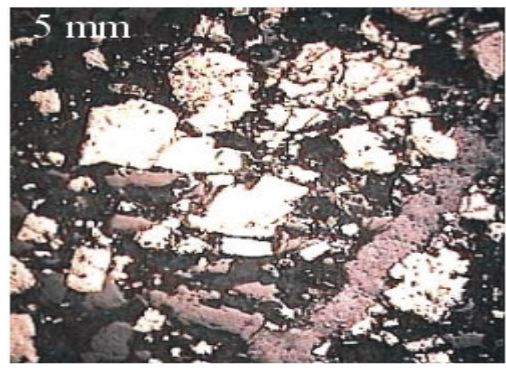

Fig. 3: Pyrite grains in a breccias texture
The average $\delta^{34} \mathrm{~S}$ values of pyrites $(9.7 \%$ ) indicate that the sulfur source was metamorphic at Muteh. However, some samples tend to magmatic source, which is result of igneous rocks in the study area.

\section{DISCUSSION}

Based on mineralogy and geological investigations, pyrites can be divided in three groups: the first group is pre-metamorphism pyrites with a minor amount of gold inclusion. These pyrites occurred in Chah-Khatoon and Senjedeh gold mine as well as Darreh-ashki granites. Other elements such as tellurium, silver, cobalt, iron, sulfur and silicium occurred in this type of pyrites, which can be as indicator of ubiquitous high value of these elements at the pyrites formation's environment ${ }^{[8]}$. The amount of cobalt in these pyrites is high and so does silicium, which concentrates at the center of grains. The second group of pyrites is syntectonic and formed along with schistosity of metamorphic rocks. Previous works ${ }^{[10,11]}$ showed that the second group of pyrites is barren, but analysis of these pyrites by SEM revealed that this group of pyrites is gold bearing minerals. The third group of pyrites occurred in highly altered rocks and accompanied with secondary chlorites and quartz veinlets. These minerals are coarse grained and contain different forms of gold. Khoei ${ }^{[8]}$ indicates that pyrrhotite at the center of this type showing high temperature and low fugacity of sulfur at the beginning of pyrite formation, then with temperature decreasing and acidity increasing of the environment pyrite has formed. Cobalt also occurred at the center of these grains with pyrrhotite but decreases toward the rim. Bismuth content increases from the center to the rim of pyrites. Arsenic also found in the third group of pyrites. SEM has shown, gold increases from the center to the rim in some pyrites, but decreases in some others.

The bulk of the $\delta^{34} \mathrm{~S}$ values at Muteh during the main mineralizing stage are restricted to average of $12.08 \%$ for three samples AB-1, AB-3 and AB4 (Table 1). This average can interpreted to indicate that the fluid redox state was below the $\mathrm{SO}_{2} / \mathrm{H}_{2} \mathrm{~S}$ boundary and $\mathrm{H}_{2} \mathrm{~S}$ was the dominant reduced sulfur species in the fluids ${ }^{[14]}$. The $\delta^{34} S$ values of pyrite separated from ores are similar to those of both pyrites from metamorphic country rocks and whole rock sulfur of metamorphic country rocks. This feature may reflect that pre-Permian metamorphic rocks (e.g., meta-volcanics and greenschists) in the Muteh area could have provided sulfur to the fluid system. Later on, the hydrothermal fluid with magmatic origin overprinted some parts of this area leaving new generation of pyrites. 
Am. J. Applied Sci., 6 (6): 1086-1092, 2009

Table 1: Sulfur isotope data from the gold-bearing pyrites of the Muteh area*

\begin{tabular}{lllllrr}
\hline Sample No. & Field No. & Rock & Mineral & Approx \%S & $\delta^{34} \mathrm{~S}(\mathrm{CDT})$ & $\delta^{34} \mathrm{~S}_{\text {hydrothermal }}$ \\
\hline AB-1 & 1-May & Biotite-schist & Pyrite & 22.7 & 16.9 & 15.65 \\
AB-2 & SE-5-2 & Biotite-schist & Pyrite & 57.0 & 2.2 & 0.98 \\
AB-3 & SE-7-2 & Meta-Volcanic & Pyrite & 65.8 & 9.1 & 7.88 \\
AB-4 & CHK-13-1 & Quartz veinlet & Pyrite & 58.2 & 13.9 & 12.68 \\
AB-5 & CHK-15-1-1 & Quartz veinlet & Pyrite & 59.8 & 6.6 & 5.38 \\
\hline
\end{tabular}

$\Delta^{34} \mathrm{~S}$ values of hydrothermal calculated based on $^{[14]}$

The $\delta^{34} \mathrm{~S}$ values of $\mathrm{AB}-2$ and $\mathrm{AB}, 5$ are not close to mean values of other samples and may indicate different generations. The $\delta^{34} \mathrm{~S}$ hydrothermal have values of these two samples are 0.98 and 5.38. These values are different from those already described (Table 1) and may show two different generations of pyrites. Sulfur isotope composition of AB-2 falls in the magmatic range ( -4 to $+4 \%$ o CDT). In the other words, sulfur isotope ratios in pyrite from the mineralization and disseminated pyrite in the host rocks are consistent with a magmatic source of the sulfur. This implies a general paucity of oxidized relative to reduced sulfur species in the hydrothermal fluid during formation of this type of pyrite. This interpretation supported by the recent study of ${ }^{[13]}$.

\section{CONCLUSION}

It seems that the source of the sulfur was not isotopically uniform or formation of pyrite not related to one event. It is empirically evident that hypogene sulfides occurring in a magmatic hydrothermal system and even throughout a mining district, rarely vary in composition by more than about \pm 5 per mil and generally vary by even less ${ }^{[2]}$. The fractionation factors calculated for $\delta^{34} \mathrm{~S}$ hydrothermal values of pyrites ${ }^{[14]}$ from Chah-Khatoon and Senjedeh open pit range from +0.98 to $+15.68 \%$. Since the $\delta^{34} \mathrm{~S}$ hydrothermal variations of pyrites are more than \pm 5 per mil, it is not convenience to relate all of them as hydrothermal with magmatic origin. As mentioned before, there are three generations of pyrite in Muteh gold district. The sulfur of these pyrites might have derived either directly from regional metamorphism that produced the metamorphic fluid or through dissolution and leaching of pre-existing sulfide-bearing minerals ${ }^{[14]}$.

Based on sulfur isotope compositions the source of the sulfides fluid of the Muteh area cannot be uniform. The $\delta^{34} \mathrm{~S}$ values in sulfides at Muteh suggest that the sulfides were formed early by fluids whose sulfur was derived from metamorphic hosts' rock sources ${ }^{[14]}$ and later overprinted by hydrothermal fluid with magmatic origin.

\section{REFERENCES}

1. Abdollahi, M.J., A. Kheradmand, M.H. Karimpour and A. Zarasvandi, 2006. Petrography of the goldbearing rocks in the Muteh district, golpaygan, Isfahan province. Proceeding of the 13th Conference of Crystallography and Mineralogy of Iran, Shahid Bahonar University, Iran, pp: 298-302. (Abstract in Persian and English).

2. Barnes, H.L., 1979. Geochemistry of Hydrothermal Ore Deposits. 2nd Edn., Wiley Canada Publishers, pp: 151.

3. Farhanghi, A., 1981. Exploration Model and Complementary of Muteh Gold Mine (the Detailed Studies of Muteh Gold Mines from 1979-1980). General Iranian Mining Company Geo. Soc. Ir. Publisher, pp: 98-100. (In Persian).

4. Farhanghi, A., 1991. Gold Prospecting in the Muteh Region, Esfahan, Iran. In: Brazil Gold'91, Ladeira, E.A. (Ed.). Balkema, Rotterdam, pp: 801-804.

5. Hassanzadeh. J., D.F. Stockli, B.K. Horton, J.A. Gary, D.L. Stockli, M. Grove, A.K. Schmitt, D.W.D. Stockli and B.K. Horton, 2008. U-Pb zircon geochronology of late Neoproterozoic-Early Cambrian granitoids in Iran: Implications for paleogeography, magmatism and exhumation history of Iranian basement. Tectonophysics, 451: 71-96. DOI: 10.1016/j.tecto.2007.11.062

6. Hodgson, C.J., 1989. The structure of shearrelated, vein-type gold deposits: A review. Ore Geol. Rev., 4: 231-273.

7. Khoei, N., 1983. Relation of gold mineralization with adjacent granites. Geological Survey of Iran, the 6th Geosciences Conference, Geology Symposium, Tehran, Iran, pp: 39-44. (Abstract in Persian and English).

8. Khoie, N., 1987. Metalogeny interpretations and gold position at Muteh deposits. Geological Survey of Iran the 10th Geosciences Conference, Geology Symposium, Tehran, Iran, pp: 122-129. (Abstract in Persian and English). 
9. Kouhestani, H., E. Rastad, N. Rasidnejad and M. Mohajjel, 2005. The role of deformation and alteration in gold mineralization in Chah-Bagh deposit shear zones [abs.]: Geological survey of Iran. Proceeding of the 23rd Symposium on Geology, Tehran, Iran, pp: 50-51. (Abstract in Persian and English).

10. Kerrich, R., 1989. Geodynamic Setting and Hydraulic Regimes: Shear Zone Hosted Mesothermal Gold Deposits. In: Mineralization and Shear Zones, Bursnall, J.T. (Ed.). Geol Assoc Can Short Course Notes, 6: 89-128.

11. Mohajjel, M., C.L. Fergusson and M.R. Sahandoi, 2003. Cretaceous-tertiary convergence and continental collision, Sanandaj-Sirjan zone, western Iran. J. Asian Earth Sci., 21: 397-412. DOI: 10.1016/S1367-9120(02)00035-4

12. Moritz, R. and F. Ghazban, 1995. Gold Mineralization in the Precambrian Basement of Zagros Belt, Esfahan Province, Iran. In: Mineral Deposits: From their Origin to their Environmental Impacts, Pasava, J., B. Kribek and K. Zak (Eds.). Balkema, Rotterdam, pp: 161-164.

13. Moritz, R., F. Ghazban and B.S. Singer, 2006. Eocene gold ore formation at Muteh, SanandajSirjan tectonic zone, Western Iran: A result of latestage extension and exhumation of metamorphic basement rocks within the zagros orogen. Econ. Geol., 101: 1497-1524. DOI: 03610128/06/3631/1497-28

14. Ohmoto, H. and R.O. Rye, 1979. Isotopes of Sulfur and Carbon. In: Geochemistry of Hydrothermal Ore Deposits, Barnes, H.L. (Ed.). Wiley, New York, pp: 798.
15. Passchier, C.W. and R.A.J. Trouw, 1998. Microtectonics. Corrected Edn., Springer-Verlag, Heidelberg, NewYork, ISBN: 10: 3540587136, pp: 289.

16. Rachidnejad-Omran N., M.H. Emami, M. Sabzehei, E. Rastad, H. Bellon A. Piqué, 2002. Lithostratigraphy and palaeozoic to palaeocene history of some metamorphic complexes from Muteh area, Sanandaj-Sirjan zone (Southern Iran). Compets Rendus Geosci., 334: 1185-1191. DOI: 10.1016/S1631-0713(02)01861-8

17. Rashidnezhad Omran, N., M. Emami, H.M. Sabzehei, A. Pique, E. Rastad, H. Bellon, T. Juteau, 2002. Metamorphic and magmatic events of the Muteh gold mine (Northeast Golpayegan). Geosci. Sci. Q. J., 11: 43-44.

18. Robert, F., K.H. Poulsen and B. Dubé, 1994. Structural analysis of lode gold deposits in deformed terrains; geological survey of Canada. Open File Report 2850, pp: 140.

19. Tabatabaei, S.M., M. Sharifi, A. Ghazifard and R. Haddadi, 1998. Gold exploration in North-East golpayagan area using Landsat TM data. Proceeding of ACRS, Geology/Geomorphology, Iran, pp: 1-1.

http://www.gisdevelopment.net/aars/acrs/1998/ts10 /ts10003.asp 